\title{
PERSAHABATAN ANTARA ALLAH DAN MANUSIA: SUATU TINJAUAN ALKITABIAH
}

\section{Henricus Pidyarto Gunawan}

\begin{abstract}
When God communicates with human, He needs to use human language and ideas. God, in one way and another, is described as human's friend. This is called anthropomorphism. The friendship among people is difinetely noble and beautiful that it is appropriate to describe the relationship between God and human. This relationship becomes very obvious from the explicit verses about God's friends as well as from the similarity in the terms used in both friendships.
\end{abstract}

Keywords: friendship, love, other-self, communion, faithfulness.

\begin{abstract}
Abstrak
Ketika berbicara dengan manusia, Allah perlu memakai bahasa dan gagasan manusia. Allah, antara lain, digambarkan sebagai sahabat manusia. Itulah yang disebut antropomorfisme. Persahabatan yang ada di antara manusia memang luhur dan indah sehingga layak dipakai sebagai salah satu gambaran untuk relasi Allah dengan manusia. Hal itu menjadi jelas dari ayat eksplisit mengenai sahabat Allah maupun dari adanya persamaan kosa-kata yang dipakai untuk kedua jenis persahabatan tersebut.
\end{abstract}

Kata kunci: persahabatan, kasih, diri yang lain, persatuan, kesetiaan.

\section{Pendahuluan}

Alkitab adalah firman Allah yang diungkapkan dalam bahasa manusia. Ketika berkomunikasi dengan manusia, Allah perlu menyesuaikan diri dengan manusia. Ia harus memakai bahasa manusia dan melukiskan diri-Nya seperti 
seorang manusia, agar lebih mudah dipahami. Itulah yang dinamakan antropomorfisme. Seperti manusia, Allah "berjalan-jalan di taman" (Kej 3:8), "memanggil manusia" dan bertanya kepada manusia, "Di manakah engkau?" (Kej 3:9), seakan-akan Dia tidak Mahatahu. Dia bisa marah (Kej 18:3), menyesal (Kej 6:3), cemburu (Kel 20:5), dan sebagainya. Konsili Vatikan II dalam konstitusi Dei Verbum 13 menulis demikian,

Jadi dalam Kitab suci - sementara kebenaran dan kesucian Allah tetap dipertahankan nampaklah "turunnya" Kebijaksanaan yang menakjubkan, "supaya kita mengenal kebaikan Allah yang tak terperikan, dan betapa Ia melunakkan bahasa-Nya, dengan memperhatikan serta mengindahkan kodrat kita."Sebab sabda Allah, yang diungkapkan dengan bahasa manusia, telah menyerupai pembicaraan manusiawi, seperti dulu Sabda Bapa yang kekal, dengan mengenakan daging kelemahan manusiawi, telah menjadi serupa dengan manusia.

Dalam Alkitab, hubungan Allah dengan umat-Nya sering dilukiskan sebagai hubungan suami dan istri, raja dan rakyat, gembala dan dombadomba, guru dan murid, dan lain sebagainya. Salah satu gambaran yang tidak begitu sering dipakai, namun sebenarnya indah dan tidak banyak berbeda dengan gambaran suami dan istri, adalah hubungan sahabat dengan sahabat. Tulisan ini bermaksud menguraikan apa yang dikatakan Alkitab tentang persahabatan antara Allah dan manusia menurut Alkitab.

\section{Persahabatan antar manusia dalam Alkitab}

Ada banyak jenis relasi yang ada antara manusia dan sesamanya. Yang satu berbeda dengan yang lain karena perbedaan dasar dan intensitas hubungannya. Ada yang kita sebut "kenalan," yakni orang yang sekedar kita kenal tanpa ada hubungan pribadi dengannya. Ada yang kita sebut "mitra,"yakni teman yang mempunyai relasi dengan kita karena keperluan tertentu, seperti relasi antara majikan dan karyawan, antara guru dan murid, antara penguasa dan bawahan, dan sebagainya. Ada juga yang kita sebut "teman" atau "sahabat," yaitu orang yang dengannya kita memiliki hubungan yang (amat) erat. Dengannya kita sering bertemu dan berkomunikasi. Dengannya kita mempunyai relasi yang melibatkan emosi 
dan afeksi kita.Menurut K.E. Davis, sebagaimana dikutip oleh G. Froggio, ${ }^{1}$ dalam persahabatan harus ada rasa suka timbal-balik saat bertemu, saling menerima apa adanya, saling percaya bahwa sahabatnya melakukan apa yang baik bagi dirinya, saling menolong dan memahami.

Persahabatan adalah salah satu bentuk relasi antar manusia yang bernilai tinggi. Ada banyak ungkapan indah tentang persahabatan yang sejati.Menurut Aristoteles, seorang yang bermartabat"akan melakukan segala sesuatu demi sahabat-sahabatnya, bahkan, jika perlu, dia akan menyerahkan nyawa bagi mereka" (Etika). ${ }^{2}$ Menurut Cicero, ada jenis persahabatan yang begitu mendalam sehingga yang satu melihat sahabatnya sebagai dirinya yang lain; mereka tidak akan saling memanfaatkan. Mereka saling "mengubah" hidup sahabatnya. Oleh karena itu, Cicero memandang persahabatan sebagai karunia tertinggi dari para dewa, sesudah karunia kebijaksanaan."”3

Siapakah seorang sahabat itu? Bagaimana sifat-sifatnya? Istilah-istilah apa yang dipakai dalam kaitan dengan persahabatan? Tulisan ini mencoba menjawab pertanyaan-pertanyaan tersebut dengan melihat apa yang dikatakan Alkitab.

\section{A. Dalam Kitab Perjanjian Lama}

Dalam kitab Perjanjian Lama dalam bahasa Indonesia (=TB-LAI), kata "teman" atau "sahabat" atau istilah yang semacam itu merupakan terjemahan dari macam-macam kata dan frasa. Dalam Mzm 41:9, "sahabat karibku yang kupercayai" merupakan terjemahan dari frasa Ibrani isy syelomi (LXX: ho anthropos tês eirēnēs mou) yang secara harfiah ber-

1 “Amicizia," dalam L. Borriello et al., Dizionario di Mistica (Vatican: Libreria Editrice Vaticana, 1999) 87.

2 Lawrence O. Richards, New International Encyclopedia of Bible Words (Grand Rapids, Mi.: Zondervam 1995) 297.

3 https://time.com/5361671/how-to-be-a-friend-cicero/\#: :text=Greek\%20philosophers\%20 such $\% 20$ as $\% 20$ Plato $\% 20$ and $\% 20$ Aristotle $\% 20$ had,Indeed $\% 20$ Cicero $\% 20$ was $\% 20$ deeply $\% 20$ influenced\%20by\%20their\%20writings. Bdk. https://www.thoughtco.com/best-friendshipquotes-2670520. 
arti “orang damaiku." Jadi, seorang sahabat adalah orang yang dengannya kita mempunyai hubungan yang baik sehingga kita merasa aman dan damai. Dalam Ayb 19:19, frasa "semua teman karibku" adalah terjemahan bebas dari frasa Ibrani metè sōd yang secara harfiah berarti "laki-laki nasihat rahasiaku." Dari ungkapan itu bisa disimpulkan bahwa orang-orang yang bersahabat bisa saling memberi nasihat rahasia atau hal-hal yang bersifat konfidensial. Dalam LXX mete sōd tadi diterjemahkan dengan hoi eidotes me, artinya: "mereka yang mengenal aku." Perlu diingat bahwa dalam Alkitab kata kerja "mengenal" seringkali berarti pengenalan yang personal dan mendalam. Memang para sahabat adalah orang yang saling mengenal secara mendalam! Masih ada beberapa ungkapan lain yang diterjemahkan dengan "teman" dalam TB-LAI. Akan tetapi, ada dua kata Ibrani yang paling sering dipakai untuk menyebut teman, yaitu: ${ }^{4}$

1) $\quad r \bar{e} a^{6}$ (dalam LXX biasanya diterjemahkan dengan plèsion atau hetairos)

Kata rēa' dipakai untukmenyebut baik kenalan atau teman biasa (misalnya pada Kej 11:3; Kel 32:27; Ayb 6:14; Mik 7:5) maupun teman yang memiliki hubungan dekat, seperti Hira, sahabat Yehuda (Kej 38:12), Yonadab, sahabat Amnon (2Sam 13:3), Husai, sahabat Daud (2Sam 15:37), dan sebagainya.

2) 'ohèb (LXX: philos)

Kata 'ohèb berasal dari kata kerja 'āhab atau 'ahēb (=mengasihi) dan dalam LXX kata ini diterjemahkan dengan philos (=pencinta). Jelas bahwa istilah ini dipakai hanya untuk menyebut sahabat karib. Persahabatan antara Daud dan Yonatan, yang menjadi model indah persahabatan antar manusia, diungkapkan dengan kata kerja 'āhab

4 Bdk. Willem A. Van Gemeren (ed.), New International Dictionary of Old Testament Theology and Exegesis (Grand Rapids, Michigan: Zondervan Publishing House; software edition, tanpa tahun);R. Laird Harris - Gleason L. Archer - Bruce K Waltke, Theological Wordbook of the Old Testament Vol. 1 \& 2 (Chicago: Moody Press, 1980); Brown, F. - Driver, S. R. Briggs, C. A., Hebrew and Eng-lish Lexicon of the Old Testament (Oxford: Clarendon Press, 1979); F. Brown - S.R. Driver - C. A. Briggs, Hebrew and Eng-lish Lexicon of the Old Testament (Oxford: Clarendon Press, 1979); Richards, Lawrence O., New International Encyclopedia of Bible Words (Grand Rapids, Michigan: Zondervan, 1991). 
(1Sam 18:1-3; 20:17). Dalam Ams 18:24 kata rēa' dan'ohēb dipakai untuk dua jenis teman yang berbeda,

"Ada teman $(r \bar{e} a$ ") yang mendatangkan kecelakaan,

tetapi ada juga sahabat ('ohèb) yang lebih karib dari pada seorang saudara."

Dengan meneliti semua ayat Perjanjian Lama yang mengandung kata "teman" atau "sahabat," dapatlah disimpulkan hal-hal berikut ini.

\section{- Sahabat sebagai orang kepercayaan}

Ada banyak kisah menarik yang mengungkapkan persahabatan manusiawi. Persahabatan itu mengandaikan adanya ikatan emosional, afeksi, bahkan kasih yang sejati.Salah satu ciri seorang sahabat adalah kredibilitasnya. Oleh karena itu, ada ungkapan mete $s \bar{d}$ (= orang nasihatku), yang menunjukkan bahwa para sahabat dapat saling memberi nasihat rahasia atau hal-hal konfidensial. Dalam Kej 38:12-20 ada kisah tentang Yehuda yang pergi ke Timna bersama dengan sahabatnya yang bernama Hira (Kej 38:13). Di sana, tanpa sepengetahuannya, Yehuda bersetubuh dengan Tamar, menantunya yang menyamar sebagai pelacur jalanan. Sebagai imbalannya Yehuda berjanji akan mengirim sekor anak kambing kepada Tamar. Untuk memenuhi janjinya Yehuda mengutus Hira, orang kepercayaannya itu, untuk menyerahkan anak kambing kepada Tamar dan mengambil kembali barangbarang tanggungan milik Yehuda. Ketika Hira tidak bisa menemukan Tamar, Yehuda berharap aibnya itu hanya diketahui mereka berdua (Kej 38:23)! Dalam 2Sam 13:3 ada kisah tentang Amnon yang mempunyai seorang sahabat bernama Yonadab. Bisa dipahami bahwa sebagai sahabat, Yonadab segera melihat kegalauan hati Amnon dan berani menanyakan penyebabnya. Kepadanya Amnon berani mengutarakan rahasia hatinya, yakni bahwa ia jatuh cinta kepada Tamar, saudarinya sendiri.

\section{- Apa yang dilakukan sahabat bagi sahabatnya}

Menurut Cicero, sahabat yang sejati bersedia melakukan segala sesuatu yang berguna atau penting bagi sahabatnya. Dalam Alkitab, ada beberapa kisah semacam itu. Bahkan kadang-kadang seorang sahabat berani 
mempertaruhkan nyawa demi kebaikan dan keselamatan sahabatnya. Ketika Saul berusaha membunuh Daud, maka Yonatan, anak Saul, berani menjadi mata-mata atau informan bagi Daud. Tentu saja apa yang dilakukan Yonatan sangat berbahaya. Ketika Saul mengetahui bahwa Yonatan berpihak pada Daud, ia berniat membunuh Yonatan dengan tombaknya (1Sam 20:33). Ada contoh lain,Husai, sahabat Daud, bersedia masuk ke sarang musuh, yakni ke dalam istana Absalom. Ia berpura-pura menjadi sahabat baru bagi Absalom yang berniat membunuh Daud, ayahnya. Dari penyamarannya yang berbahaya itu dia bisa mengirim berita-berita kepada Daud. Ketika Ahitofel menasihati Absalom agar segera mengejar dan membunuh Daud, Husai berhasil meyakinkan Absalom bahwa nasihat Ahitofel itu keliru. Dengan demikian, Daud mempunyai cukup waktu untuk melarikan diri (2Sam 15-17).

- Mengasihi sahabat sebagai dirinya yang lain

Sahabat adalah orang yang mengasihi sahabatnya. Karena itu tepat sekali kalau untuk menyebut sahabat dipakai kata 'ohēb (=LXX: philos), yang berarti pencinta, sedangkan kata bendanya 'ah $b \hat{a}$ (=LXX: philia) dipakai untuk menyebut persahabatan (Ams 17:9). Dalam persahabatan yang sejati kasih menjadi unsur penting yang menyatukan. Kadang terjadi bahwa hubungan kasih antara dua sahabat bisa melebihi kasih kepada saudara sendiri, seperti dikatakan pada Ams 18:24, "Ada teman yang mendatangkan kecelakaan, tetapi ada juga sahabat yang lebih karib dari pada seorang saudara."

Kasih persahabatan tampak amat jelas dalam hubungan Daud dan Yonatan (1Sam 18 -2Sam 1). Persahabatan mereka dianggap sebagai model persahabatan yang sejati. Kisah mereka diawali dengan kalimat ini, "Ketika Daud habis berbicara dengan Saul, berpadulah jiwa Yonatan dengan jiwa Daud; dan Yonatan mengasihi dia seperti jiwanya sendiri" (1Sam 18:1). Ungkapan ini diulang dua kali lagi pada 1Sam 18:3 dan 20:17.Dari situ dapat disimpulkan bahwa bagi Yonatan, Daud adalah dirinya yang lain. Gagasan yang serupa kita temukan dalam Ul 13:7, di mana ada ungkapan "temanmu yang bagaikan jiwamu sendiri”" (tetapi dalam TB-LAI diterjemahkan dengan 
"sahabat karibmu").

Persahabatan yang mendalam antara Yonatan dan Daud diungkapkan juga dengan istilah lain, yaitu kata Ibrani $\eta[\alpha 4 \pi \varepsilon 4 \sigma[$ (=sangat suka kepada). Dikatakan pada 1Sam 19:1 bahwa "Yonatan, anak Saul, sangat suka kepada Daud.'Demi kasihnya kepada Daud, Yonatan bersedia melakukan apa saja yang dikehendaki sahabatnya itu (1Sam 20:4). Ketika Daud harus melarikan diri, "dia dan Yonatan bercium-ciuman dan bertangis-tangisan" (1Sam 20:41). Ketika sempat bertemu kembali, kedua orang itu mengikat lagi perjanjian di hadapan Tuhan (1Sam 23:18). Ketika mendengar bahwa Yonatan telah gugur dalam perang, Daud meratapinya dengan sangat. Jika selama ini lebih ditampakkan kasih Yonatan kepada Daud, sekarang kasih Daudlah yang tampak dengan jelas. Tentang Yonatan dia berkata,

"Merasa susah aku karena engkau, saudaraku Yonatan, engkau sangat ramah kepadaku;

bagiku cintamu lebih ajaib dari pada cinta perempuan" (2Sam 1:26).

\section{- Sahabat itu setia}

Salah satu ciri persahabatan yang sejati adalah kesetiaan. Yesus bin Sirakh memuji sahabat yang setia sebagai sesuatu yang tidak ternilai harganya (Sir 6:14-17) dan yang tidak bisa ditukar dengan uang (Sir 7:18). Daud meminta kesetiaan Yonatan pada perjanjian yang telah mereka ikat (1Sam 20:8), dan Yonatan memang setia pada janji-janjinya itu (1Sam 20:35). Ketika Husai, diminta oleh Daud untuk berpura-pura menjadi sahabat Absalom, berkatalah Absalom kepadanya, "Inikah kesetiaanmu kepada sahabatmu? Mengapa engkau tidak pergi menyertai sahabatmu itu?" (2Sam 16:17). Sesungguhnya pengkhianatan seorang sahabat itu menyakitkan (Mzm 41:9).

\section{B. Dalam Kitab Perjanjian Baru}

Dalam kitab Perjanjian Baru, istilah yang dipakai untuk menyebut teman atau sahabat lebih sederhana daripada dalam kitab Perjanjian Lama. ${ }^{5}$

5 Bdk. Collin Brown (ed.), The New International Dictionary of the New Testament. Vol I-II-III (Exeter, Devon: The Paternoster Press, 1975); Spiros Zodhiates(ed.), The Complete Word 
Dalam TB-LAI, semua kata "teman" atau "sahabat" merupakan terjemahan dari kata Yunani philos dan hetairos, kecuali pada Kis 4:23 dan 24:23 (TBLAI) di mana kata "teman-teman" adalah terjemahan dari kata Yunani hoiidioi yang sebenarnya berarti "orang-orang sendiri” atau yang semacam itu. Kata hetairos muncul hanya 3 kali dalam seluruh Perjanjian Baru dan semuanya ada dalam Injil Matius $(20: 13 ; 22: 12 ; 26: 50) .{ }^{6}$ Namun,sayang, dalam TB-LAI kata hetairos pada Mat 20:13 dan 22:12 diterjemahkan dengan "saudara." Jika kita melihat konteksnya, maka ketiga kata hetairos dipakai oleh seseorang untuk menegur orang lain. Jadi, hetairos dipakai bukan untuk mengungkapkan persahabatan yang sejati. Kata inilah yang dipakai Yesus untuk menegur Yudas Iskariot yang mengkhianati Diri-Nya dengan ciuman (Mat 26:50). Kata lain yang jauh lebih sering dipakai dalam kitab Perjanjian Baru adalah philos (Mat 11:19; Luk 7:6; 7:34; Yoh 3:29; dsb.).

Dari konteks dapat disimpulkan bahwa philos adalah sahabat dekat, lebih dari sekedar kenalan. Pada Luk 14:10 kata itu dipakai oleh tuan rumah untuk menyapa orang yang dia persilahkan duduk di tempat paling depan. Pada Yoh 3:29 sahabat mempelai adalah teman terdekat sang mempelai laki-laki yang biasanya memiliki peranan penting dalam seluruh proses pernikahan. Dia itu lebih dari apa yang disebut best man dalam pernikahan orang barat. Orang-orang Farisi dan ahli Taurat memandang Yesus sebagai sahabat para pendosa karena Ia bersedia makan dan minum bersama mereka (Luk 7:34). Yesus lebih dari sekedar kenalan para pendosa sebab bagi orang Yahudi partisipasi pada makan-minum bersama mengungkapkan persahabatan di antara mereka yang ikut dalam perjamuan tersebut. Seorang sahabat tidak enggan untuk mengganggu sahabatnya dan meminjam makanan, bahkan di tengah malam. Tetapi dia sendiri juga rela menerima

Study Dictionary: New Testament (Iowa Falls, Iowa: Wordld Bible Publishers, Inc., 1992; Verlyn D. Verbrugge, The NIV Theological Dictionary of New Testament Words (Grand Rapids, Michigan: Zondervan Publishing House, 2000).

6 Atau 4 kali, jika kita menerima Mat 11:16 menurut Textus Receptusseperti yang dipakai dalam TB-LAI, "Mereka itu seumpama anak-anak yang duduk di pasar dan berseru kepada teman-temannya (hetairois)." Namun, kebanyakan manuskrip memakai kata heterois (= kepada yang lain"). Lih. Spiros Zodhiates, The Complete Word Study Dictionary: New Testament (Iowa Falls, Iowa: World Bible Publishers, Imc., 1992) 663. 
sahabatnya yang datang secara mendadak di tengah malam (Luk 11:5-8). Yesus memanggil para pengikut-Nya dengan sebutan "sahabat-sahabatKu” (Luk 12:4). Sebagaimana Hira, sahabat Yehuda, dan Yonadab, sahabat, Amnon,boleh mengetahui "rahasia"sahabat mereka, begitu juga Yesus berkata kepada para murid-Nya, "Aku tidak menyebut kamu lagi hamba, sebab hamba tidak tahu, apa yang diperbuat oleh tuannya, tetapi Aku menyebut kamu sahabat, karena Aku telah memberitahukan kepada kamu segala sesuatu yang telah Kudengar dari Bapa-Ku" (Yoh 15:15).Menurut Aristoteles seorang sahabat sejati rela memberikan nyawa untuk sahabatnya. Begitu juga Yesus mengasihi sahabat-sahabatnya sampai menyerahkan nyawa-Nya (Yoh 15:13).

Data di atas tidaklah lengkap, namun cukup untuk melukiskan bagaimana Alkitab melukiskan keluhuran persahabatan yang ada di antara manusia. Sahabat yang sejati tidak mudah ditemukan. Dalam kitab Ayub tampak bahwa para sahabat Ayub tidak sepenuhnya memenuhi persyaratan sahabat sejati. Dalam kitab Sirakh banyak dimuat nasihat untuk berhati-hati dalam memilih sahabat (misalnya pada pasal 6-7). Yesus bin Sirakh menegaskan bahwa sahabat yang setia adalah anugerah yang luar biasa dan yang diperoleh oleh orang yang takut akan Tuhan (Sir 6:14-17).

\section{Persahabatan Allah dengan manusia}

Beberapa kali kita temukan ayat Alkitab yang mengungkapkan persahabatan antara Allah dengan manusia. Orang pertama yang disebut sahabat Allah adalah Abraham, sebagaimana dikatakan dalam 2Taw 20:7, "Bukankah Engkau Allah kami yang menghalau penduduk tanah ini dari depan umat-Mu Israel, dan memberikannya kepada keturunan Abraham, sahabat-Mu itu, untuk selama-lamanya?" Sebutan yang sama kita temukan juga pada Yak 2:23. Patut juga diketahui bahwa frasa "Abraham yang Kukasihi” pada Yes 41:8 (TB-LAI) sebenarnya dapat juga diterjemahkan dengan "Abraham, sahabat-Ku," seperti pada BIS dan kebanyakan Alkitab dalam bahasa Eropa. Orang kedua yang disebut sahabat Allah adalah Musa. Kepadanya Allah berbicara dari muka ke muka bagaikan berbicara kepada temannya (Kel 33:11). Dalam perkembangannya, setiap manusia yang memiliki kebijaksanaan adalah sahabat Allah (Kebij 7:14.27). 
Persahabatan sejati yang sering terjadi di antara manusia sungguh layak untuk melukiskan hubungan antara Allah dan manusia. Hal ini menjadi jelas tidak hanya dari adanya beberapa orang yang disebut secara eksplisit sebagai "sahabat Allah," melainkan juga dari kenyataan literer bahwa ada banyak istilah yang dipakai dalam kaitan dengan persahabatan antar manusia dipakai juga dalam konteks persahabatan antara Allah dan manusia. Berikut ini beberapa kata penting semacam itu: ${ }^{7}$

- Kata “mengasihi” (Ibrani: 'āhêb) dipakai untuk mengungkapkan persahabatan antar manusia tetapi juga persahabatan antara Allah dan manusia. Sebagaimana kata kerja ini dipakai beberapa kali untuk mengungkapkan cinta Yonatan kepada Daud (1Sam 18:1.3), begitu juga kata ini dipakai sebanyak 23 kali untuk Allah yang mengasihi umat-Nya (Ul 4:37; 7:13, dll.) dan 22 kali untuk manusia yang mencintai Allah (Ul 6:5; 7:9 dll.).

- Kata Ibrani 'ahabē dan kata Yunani philia (= kasih; persahabatan) dipakai baik untuk menyebut persahabatan antar manusia (1Sam 18:3; 20:17; Sir 6:17; 1Mak 10:23) maupun untuk persahabatan antara Allah dan manusia (U1 7:8; 2Taw 2:11; Kebij 7:14; Ams 17:9. Notabene: dalam TB-LAI kata 'ahabē dalam Ams 17:9 diterjemahkan dengan "kasih," bukan dengan "persahabatan."

- Kata Ibrani $\delta \alpha 4 \beta \alpha \theta$ (= melekat) bisa dipakai untuk mengungkapkan persatuan atau kedekatan relasi di antara para sahabat (Ams 18:24) maupun untuk kedekatan relasi manusia dan Allah (Ul 4:4; Mzm 63:9).

- Dalam 1Sam 19:1 perasaan suka Yonatan kepada Daud, sahabatnya, diungkapkan dengan kata Ibrani $\eta[\alpha 4 \pi \varepsilon 4 \sigma[$ (= suka akan). Kata yang sama dipakai untuk mengungkapkan rasa suka Tuhan kepada umat-Nya (Ul 14:8; Mzm 22:9; 41:12) dan rasa suka manusia kepada Allah (Mzm 73:25).

7 Lih. R. Laird Harris - Gleason L. Archer - Bruce K Waltke, Theological Wordbook of the Old Testament Vol. 1 \& 2 (Chicago: Moody Press, 1980); Brown, F. - Driver, S. R. - Briggs, C. A., Hebrew and Eng-lish Lexicon of the Old Testament (Oxford: Clarendon Press, 1979); F. Brown - S.R. Driver - C. A. Briggs, Hebrew and Eng-lish Lexicon of the Old Testament (Oxford: Clarendon Press, 1979). 
- $\quad$ Dari konteksnya, kata Ibrani sôd (harfiah: nasihat atau nasihat rahasia) bisa diterjemahkan dengan "persahabatan." Kata ini dipakai baik untuk menyebut persahabatan antar manusia (Ayb 19:19) maupun untuk persahabatan antara Allah dan manusia (Ayb 29:4; Mzm 25:14;).

Dapat kita lihat bagaimana kosa-kata yang berlaku di dunia persahabatan antar manusia kita temukan juga dalam kaitan dengan persahabatan antara Allah dan manusia. Kemiripan-kemiripan tersebut masih bisa dilengkapi dengan melihat kemiripan-kemiripan dalam sifat-sifat persahabatan, seperti: kesetiaan, keterbukaan satu sama lain, usaha untuk berbuat baik untuk pihak lain, dan sebagainya. Akan tetapi, apa yang sudah diuraikan di atas kiranya cukup untuk tujuan penulisan makalah ini.

\section{Penutup}

Sudah dikatakan pada awal tulisan ini bahwa dalam berkomunikasi dengan manusia, Allah perlu membandingkan dirinya dengan manusia. Itulah yang disebut antropomorfisme dalam Alkitab. Hubungan Allah dengan manusia sering dilukiskan sebagai hubungan Pencipta - ciptaan, Raja rakyat, Gembala - domba, Bapa - anak, Suami - istri, dan sebagainya. Tulisan ini hanya bermaksud menunjukkan bagaimana luhurnya persahabatan yang sejati antara manusia dan karenanya sungguh layak untuk dipakai sebagai perbandingan untuk hubungan Allah dan manusia. Hal itu menjadi jelas tidak hanya pada ayat-ayat yang secara eksplisit menyebut Abraham, Musa atau orang bijak sebagai sahabat Allah, tetapi tampak juga secara tidak langsung dari banyaknya kosa-kata yang dipakai baik untuk mengungkapkan relasi persahabatan antar manusia maupun antara Allah dan manusia.

Gagasan Allah sebagai sahabat manusia amat menarik dan mengesankan mereka yang menghargai dan menghayati persahabatan dengan sesamanya. Mungkin gagasan ini perlu lebih diwartakan kepada umat. Hal ini amat selaras dengan ajaran Konsili Vatikan II dalam konstitusi dogmatis Dei Verbum no. 2 yang menyatakan bahwa Allah menyapa manusia sebagai sahabat-sahabat-Nya (lih. Kel 33:11; Yoh 15:14-15). 